\title{
The (mis)match between sexuality education programs in school and the expectations of Ecuadorian adolescents
}

\section{El (des)encuentro entre los programas de educación sexual en los Colegios y las expectativas de los adolescentes ecuatorianos}

\author{
Jessica Castillo-Núñez ${ }^{1}$ (D), Ilse Derluyn ${ }^{2}$ iD Martin Valcke $^{3}$ (D) \\ ${ }^{1}$ Faculty of Philosophy, Letters and Educational Sciences, University of Cuenca, Cuenca Ecuador. \\ 2 Department of Social Work and Social Pedagogy \& Centre for the Social Study of Migration and Refugees, Ghent \\ University, Gent, Belgium. \\ ${ }^{3}$ Department of Educational Studies, Ghent University, Gent, Belgium. \\ Autor para correspondencia: jessica.castillo@ucuenca.edu.ec \\ Fecha de recepción: 18 de junio de 2019 - Fecha de aceptación: 23 de octubre de 2019
}

\begin{abstract}
Considering the relevance of adolescents' voices in the design and implementation of sexuality education programs, the current study explores adolescents' perceptions of ongoing sexuality education they are receiving at school (SSE) and perceptions about their teachers' professionalism towards this topic (SEPT) in Ecuador. A multi-stage stratified cluster sampling procedure was followed to involve 702 adolescents between 11 and 19 years old in the study. Participants perceptions of SSE and SEPT were assessed based on a Likert scale survey encompassing 15 closed and 4 open questions. Responses were analyzed in relation to their gender, parental migration status, age and geographical location. Adolescents expressed high satisfaction with sexuality education received at school (SSE) and were mildly satisfied about their teachers' competences regarding sexuality education (SEPT). Multinomial logistic regression analyses revealed slight differences in relation to the socio-demographic variables. Answers to open-ended questions reflected a strong influence of a biological approach on sexuality education. Given the satisfaction levels in SSE and SEPT, and the contrasts between the biological approach and the overarching Ecuadorian framework, the results have clear implications for the design and implementation of future sexuality education programs and training teacher proposals.
\end{abstract}

Keywords: Sexuality education, teachers' professionalism, adolescents' satisfaction, Ecuador.

\section{RESUMEN}

Considerando la relevancia de las voces de los adolescentes en el diseño e implementación de los programas de educación en sexualidad, el estudio actual explora las percepciones de los adolescentes sobre la educación sexual actual que reciben en la escuela (SSE) y las percepciones sobre el profesionalismo de sus docentes con respecto a este tema (SEPT) en Ecuador. Mediante un procedimiento de muestreo por grupos estratificados en varias etapas se involucró a 702 adolescentes entre 11 y 19 años de edad en el estudio. Las percepciones de los participantes de SSE y SEPT se evaluaron en base a una encuesta tipo Likert con 15 preguntas cerradas y 4 preguntas abiertas. Las respuestas se analizaron en relación con su género, estado migratorio de los padres, edad y ubicación geográfica. Los adolescentes expresaron un nivel alto de satisfacción con la educación sexual recibida en la escuela (SSE) y un nivel medio de satisfacción con las competencias de sus maestros con respecto a la educación sexual (SEPT). Los análisis de regresión logística multinomial revelaron ligeras diferencias en relación con las variables sociodemográficas. Las respuestas a las preguntas abiertas reflejaron la fuerte influencia de un enfoque biológico en la educación en sexualidad. Dados los niveles de satisfacción en SSE y SEPT, y los contrastes entre el enfoque biológico y el marco ecuatoriano general, los resultados tienen implicaciones claras para el diseño y la implementación de futuros programas de educación en sexualidad y la capacitación de propuestas de maestros.

Palabras clave: Educación en sexualidad, profesionalismo de docentes, satisfacción de los adolescentes, Ecuador. 
1.

INTRODUCTION

In most countries, the school system is considered a formal setting for the implementation of sexuality education in adolescents, as schools represent a safe environment, and large groups of adolescents from diverse backgrounds can be targeted (Bay-Cheng, 2003; Thomas \& Aggleton, 2016). Moreover, the role of the school in providing sexuality education is supported by parents, as well as by the majority of adolescents (Walters \& Hayes, 2007). Nevertheless, sexuality education in a school context is challenging. In the present article, we examined how the design of sexuality education programs is aligned with students' expectations and probe students' perceptions about their teachers' expertise in this field.

\section{The design of sexuality education programs}

The relevance of providing sexuality education within the school context is inexorably intertwined with the attention paid to its design and implementation process. Discussions about an appropriate design for sexuality education in schools - in terms of content, time, methodology, evaluation, and expected outcomes - reflect a variety of challenges. By definition is the design of sexuality education programs in schools linked to cultural values (Walters \& Hayes, 2007), as well as to myths and stereotypes about sexuality and sexuality education (Das, 2014). Discussions reiterate concerns, pressures and censures about what sexuality education should (not) imply and how it should be included into the school curriculum (Bay-Cheng, 2003; Walters \& Hayes, 2007; Das, 2014).

Debates about sexuality education in schools mirror two main controversies. First, recent approaches of sexuality education have shifted from a focus on isolated and concrete aspects of sexuality (e.g., contraceptives, STDs sexually transmitted diseases, AIDS - acquired immune deficiency syndrome, etc.), strongly based on health interventions (Darré et al., 2015), to a holistic view focusing on gender and sexuality rights (IPPF, 2009) and promoting a "whole school" approach (Thomas \& Aggleton, 2016). However, despite these changes, scholars have concluded that most current sexuality education programs in schools still concentrate on technical, physical and risk aspects related to sex (Giami et al., 2006; Kirby, Obasi, \& Laris, 2006; Darré et al., 2015). Second, there are deliberations about how sexuality education should be nested within the school curriculum: (a) as a stand-alone subject within the curriculum, often offered as elective course (Walters \& Hayes, 2007) and taught by "experts"; (b) integrated within an existing mainstream subject (such as biology); or (c) as a transversal axis within the curriculum, meaning that sexuality education should be embedded in every subject. Consequently, schoolteachers should be able to address it within their subjects (Martin, 2007) even in every space or moment of the school, aiming at a "whole school" approach; (d) a combination of these diverse modalities. Such a combination could be a transversal axe design but could also result in defining a specific sexuality education course in the curriculum (Thomas \& Aggleton, 2016).

While it has been argued that the sensitive nature of sexuality education influences the approach of program design, a standardized proposal is still not available. There seems to exist a consensus about the inclusion of the following components: (a) cognitive components building on a scientific-based knowledge; (b) affective components introducing values attitudes and beliefs; and (c) behavioral components introducing the development of skills (Forrest et al., 2004; Allen, 2005; Giami et al., 2006; Allen, 2008; Helmich, 2009; Barr et al., 2014; Schmidt, Wandersman, \& Hills, 2015; Thomas \& Aggleton, 2016). Still, knowledge, behaviors and attitudes could be fostered through different approaches. From a comprehensive perspective approach, these three different components should be addressed via topics as gender, sexual health, sexual rights, violence, diversity and relationships (IPPF, 2009; Thomas \& Aggleton, 2016). While these different components inform the design of sexuality education programs, it is still necessary to consider the particular context with which these programs interact, for example through local values, religion and geographical differences (Walters \& Hayes, 2007; Hunt \& Ott, 2014). For instance, contexts may differ in their views related to patterns of virginity or heterosexuality (UNESCO, 2015) or rural communities may differ from urban contexts in sexual practices, knowledge and beliefs (Tenorio Ambrossi, 2004). Nevertheless, although sexuality education from a comprehensive approach should be adapted to local contexts; there are topics that are essential in order to maintain the programs' quality and to meet international standards (UNESCO, 2015).

Being context-sensitive also requires that sexuality education programs are aligned with adolescents' specific circumstances and unique characteristics (DiCenso, Guyatt, Willan, \& Griffith, 2002; Helmich, 2009; MacDonald et al., 2011; Schmidt et al., 2015; Simovska \& Kane, 2015; Thomas \& Aggleton, 2016). Literature points at the need to teach sexuality education in a developmentally appropriate way, acknowledging that adolescents' development may differ in specific cultures and contexts (World Health Organization, 2010; Muhanguzi \& Ninsiima, 2011; Das, 2014; Thomas \& Aggleton, 2016).

\section{Teachers' point of view on sexuality education}

Key to ensure school-based sexuality education programs succeeding in encompassing adolescents' needs and interests is the professional role of teachers. While wellprepared teachers are key to effective sexuality education (Barr et al., 2014), research concludes that a majority of teachers assigned to teach sexuality education have received little or no formal related training and do not feel empowered for this responsibility (Cohen, Byers, Sears, \& Weaver, 2004; Walters \& Hayes, 2007; Das, 2014). At the same time, research shows that adolescents are aware of this weakness in teacher competences (Allen, 2005), and adolescents' perceptions of their teachers' professional preparation to (not) address sexuality education influence their motivation and engagement towards the subject (MacDonald et al., 2011; Adams Tucker et al., 2016). One reason is that teaching sexuality education often evokes feelings of fear, embarrassment, anxiety, confusion and discomfort in teachers (Milton et al., 2001; Kehily, 2002), as well as preoccupations about being given a very different educational role (e.g., counsellor) (Helleve et al., 2011) and the fact they might no longer solely be seen as a 'teacher' (Oulton, Day, Dillon, \& Grace, 2004). Moreover, teachers' own values influence their involvement in sexuality education programs, since they 
(implicitly or explicitly) integrate their intimacy, values and beliefs into a subject that is labelled as 'sensitive and controversial' (Huberman, Grounauer, Marti, \& Neufeld, 1993; Helleve et al., 2011). Last, teachers often feel illequiped to engage in a sexuality education program which builds onto paradigms they do not believe in or understand (Walters \& Hayes, 2007; Preston, 2013).

\section{Adolescents' voices about sexuality education}

Adolescents' voices are hardly heard in the design of sexuality education programs (DeMaria et al., 2009). While an understanding of the target group is crucial in view of adolescents' engagement in the curriculum (Allen, 2008), their voices remain largely absent in decisions about the sexuality education curriculum in the formal educational system (Bay-Cheng, 2003; MacDonald et al., 2011; Thomas \& Aggleton, 2016), since in most cases, adults are those who design and decide on sexuality education programs (Santelli et al., 2006; Giami et al., 2006; Hirst, 2008).

The same gap is noted in the research literature. Available research focuses mainly on outcomes, particularly in adolescents' behavior after sexuality education (Suellentrop, 2011), with a focus mainly on the use of contraceptives or abstinence approaches (Kirby, 2002; Wilson, Goodson, Pruitt, Buhi, \& Davis-Gunnels, 2005; Rijsdijk et al., 2011; Haberland \& Rogow, 2015) and on the obstacles when implementing sexuality education in schools (Eisenberg et al., 2013; Simovska \& Kane, 2015).

Yet, very little is known about the fit between sexuality education provided and adolescents' expectations. Therefore, the current study aimed at examining the perspectives of adolescents' students about the sexuality education implemented in their school context. Two research questions were put forward: (1) To what extent are adolescents satisfied with the sexuality education they receive in schools? and (2) To what extent do adolescents consider their teachers performing well when addressing sexuality education? To answer these questions, we measured, firstly, adolescents' satisfaction with the sexuality education they have been receiving (SSESatisfaction Sexuality Education), and, secondly, adolescents' perceptions about the Sexuality Educational Teachers' Professionalism (SEPT-Sexuality Education Professionalism of Teachers).

Since sexuality is a complex human dimension, its conceptualization differs according to contexts, groups and even individuals. To be sensitive to these differences, the present study also tackled background variables such as gender, age, geographical location and the situation of adolescents with emigrated parents. Participants' geographical location calls for particular attention, given the context of the study (Ecuador), where we note, as in other Latin American contexts, the emergence of 'new ruralities' and its influence on adolescents' sexuality (Pascual, 2013). The variable 'adolescents with emigrated parents' refers to a growing group of Ecuadorian children and adolescents whose parents have emigrated while they themselves stay in the home country (Jokhan, 2008).

\footnotetext{
${ }^{1}$ Average ages: Basic education: $8^{\text {th }}$ grade: 12 years old; $9^{\text {th }}$ grade: 13 years; $10^{\text {th }}$ grade: 14 years; secondary education: $1^{\text {st }}$ grade: 15 years old; $2^{\text {nd }}$ grade: 16 years; $3^{\text {rd }}$ grade: 17 years.
}

\section{METHODS}

\subsection{Study context}

The study was conducted in Ecuador, a country with one of the highest rates of teenage pregnancy in Latin-America (Castro \& Salinas, 2017). In Ecuador, the recognition of adolescents' rights on sexuality education is embedded in the constitution, with schools as major stakeholders through the implementation of the Comprehensive Sexuality Education (CSE) framework (Educativo, 2012). CSE, that is incorporated as a compulsory part of mainstream curriculum, goes beyond a narrow focus on abstinence and contraceptives, and incorporates gender rights, is explicitly secular in nature, and considers sexuality as inherent to human beings. Moreover, CSE is designed in a way that it guarantees the development of inter-related knowledge, skills and attitudes, at all educational levels, and both in public and private schools. To reach this goal, a strategy was put forward by the Ministry of Education that puts CSE as a transversal axis within the school curriculum. This suggests that every teacher, at any educational level and responsible for any subject, should be able to address sexuality education in his/her classroom.

\subsection{Participants}

Participants in the present study are adolescents attending public secondary schools from urban and rural areas in cantons of Azuay province in Ecuador. A multi-stage stratified cluster sampling procedure was followed. In the sampling procedure, we only included schools offering both upper basic educational $\left(8^{\text {th }}, 9^{\text {th }}\right.$ and $10^{\text {th }}$ grade $)$ and secondary education $\left(1^{\text {st }}, 2^{\text {nd }}\right.$ and $\left.3^{\text {rd }}\right)$.

In a first sampling step, on the basis of demographic information of the Azuay region, eight cantons (50\% of all cantons) were selected with the highest rates of international emigration (INEC, 2010). Further, on the basis of the Azuay public schools' database (Ministry of Education of Ecuador, 2012), 18 schools were randomly selected from these eight cantons:

- From five cantons: one urban and one rural high school (10 in total);

- From two rural cantons: one school from each canton ( 2 in total); and

- From the capital canton: two urban, two rural, and two urban-rural schools (6 in total).

In a second step, three clusters of classes were selected from each school:

- cluster 1: $8^{\text {th }}-9^{\text {th }}$ grade classes $^{1}$ (early adolescence);

- cluster 2: $10^{\text {th }}$ grade classes and $1^{\text {st }}$ year secondary education classes (middle adolescence); and

- cluster 3: $2^{\text {nd }}$ and $3^{\text {rd }}$ year secondary education classes (late adolescence).

Thirdly, each cluster was screened in collaboration with a teacher or psychologist. For each cluster, the class with the largest proportion of students with emigrated parents was selected. Fourthly, to ensure the gender balance and avoid stigmatization of adolescents with emigrated parents, we randomly selected eight girls and eight boys from the class with the largest proportion of students with emigrated 
parents. In this phase, the random selection focused on developing a subgroup of at least fifteen adolescents.

The final sample consisted of 780 adolescents between 11 and 19 years old. Considering the aim of the current study, we only included the data of those adolescents who reported in the survey they already received sexuality education during high school, bringing the final number of participants to 702 .

The final sample reflects the demographics characteristics of the population in Azuay in terms of gender, age and geographical location (INEC, 2010). Yet, regarding the emigration status of the parents, we purposively included a larger proportion (see Table 1).

Table 1. Socio-demographic characteristics of the study sample.

\begin{tabular}{clcc}
\hline \multicolumn{2}{c}{ Respondent characteristics } & $\mathrm{n}$ & $\%$ \\
\hline Gender & Male & 354 & 50.4 \\
& Female & 348 & 49.6 \\
\hline Parental & None & 338 & 48.1 \\
Migration & One parent & 121 & 17.2 \\
& Two parents & 243 & 34.6 \\
\hline \multirow{2}{*}{ Age* } & Early & 165 & 23.5 \\
& Middle & 360 & 51.3 \\
& Late & 177 & 25.2 \\
\hline Geographical & Urban & 350 & 49.9 \\
Location & Rural & 266 & 37.9 \\
* & Urban-Rural** & 86 & 12.3 \\
latly adolescence: 11-14 years; middle adolescence: 15-16; \\
** Adolescents from both rural and urban areas attended this \\
\multicolumn{3}{c}{ school. }
\end{tabular}

\subsection{Procedure}

Authorization for this study was obtained from the Ecuadorian Ministry of Education, and ethical clearance from the Ethical Committee of the Faculty of Psychology and Educational Sciences of Ghent University. Once authorities of the schools verified the authorization letter of the local authorities and the Ministry of Education, all selected schools accepted to participate in the study. Trained researchers administrated the survey in each school.

Survey administration started by informing adolescents about the study aims. The study conditions were explained (voluntary participation, the right to withdraw from participation at any time, confidentiality and anonymity), and contact information of the researcher was given in case of further information or assistance needed. Next, adolescents were invited to give their informed consent by signing a form. Two schools requested to obtain first individual parents'/guardians' authorization for underage adolescents prior to the survey administration. From these schools, 30 and 31 adolescents respectively (of the 45 in each high school) received parental consent and participated. In the other schools, none of the invited adolescents refused to participate.

After obtaining informed consent, adolescents completed the survey individually, in a classroom and in the presence of their classroom mates and the researcher. Instrument administration took on average twenty minutes. After completion, participants received a free snack and a drink.

\subsection{Research instruments}

To conduct the study, a survey consisting of two scales was designed (Annex 1). One scale evaluated the level of satisfaction of adolescents as to the sexuality education they received at school (SSE). Building on the general guidelines for curriculum design from the Ministry of Education of Ecuador (Ministerio Education, 2012), 4 items and 2 open-ended questions were presented to the adolescents (e.g., items: during sexuality education classes, topics being addressed, were interesting for me; during the class, I felt comfortable when sexuality education topics were addressed; open-ended questions: in which courses have you received sexuality education; what did you like the most about the sexuality education classes you participated in?). Adolescents rated each scale item on a 6-point Likert scale, expressing their agreement (1 'strongly disagree' -6 'totally agree'). Cronbach's $\alpha$ reflected an acceptable to good level of internal consistence ( $\alpha=0.73)$.

The second scale assessed adolescents' perceptions of the Sexuality Education Professionalism of Teachers (SEPT). The scale consisted of 6 items and was developed on the base of Bandura (2006) and WHO (2010) (e.g., my teachers could motivate us to feel comfortable as we addressed issues relating to sexuality education; my teachers could improve our knowledge about sexuality). Adolescents were also asked to rate their level of agreement with each scale item (1 'strongly disagree' - 6 'totally agree'). Cronbach's alpha reflects a good reliability $(\alpha=0.79)$.

Additionally, background questions were presented to get information about adolescents' background characteristics (gender, age, geographical location and migration status of the parents).

A pilot version of the survey was reviewed by two experts, resulting in three scale items being revised. Next, this first pilot version was tested, involving 72 adolescent students from three different public high schools (not included in the current sample) to check completeness, comprehensibility and feasibility of the instrument. After pilot testing, two items were reformulated, three items were enriched with a clarification and two open questions were incorporated. The structure and the format of the questionnaire were qualified as adequate.

\subsection{Data analysis}

On the base of a descriptive data analysis, a first picture was developed of SSE and SEPT, focusing on potential differences related to gender, age, geographical location and parents' migration status. Since the data reflected overall high scores, the original Likert scale from 1-6 was re-coded into three new, discrete variables: 1,2 and 3 . Collapsing scale levels is often applied in research related to sensitive topics, when respondents select a smaller range of values within a broader scale (see e.g., Matthias, Lubben, Atchison, \& Schweitzer, 1997). We applied the Linacre (2002) guidelines to collapse response values categories. The recoding is as follows: the value 1 indicates that adolescents agree to a lesser extent, while 3 indicates that the respondents totally agree with a statement. Frequencies and percentages were calculated based on the re-categorized scale. In addition, the answers to the two open questions included in the SSE scale were clustered into categories by grouping responses belonging 
Table 2. Descriptive analysis of the key research variables in relation to the participants' background variables $(\mathrm{N}=702)$.

\begin{tabular}{cccccccc}
\hline \multicolumn{2}{c}{ Respondent characteristics } & \multicolumn{3}{c}{ Value $^{\mathrm{a}}$ for SSE } & \multicolumn{3}{c}{ Value $^{\mathrm{a}}$ for SEPT $^{\mathrm{d}}$} \\
& & 1 & 2 & 3 & 1 & 2 & 3 \\
\hline \multicolumn{2}{c}{ Total group } & $107(15.2)^{\mathrm{b}}$ & $247(35.2)$ & $348(49.6)$ & $213(30.3)$ & $255(36.3)$ & $234(33.3)$ \\
\hline \multirow{2}{*}{ Gender } & Male & $65(17.8)$ & $128(36.1)$ & $161(45.4)$ & $122(34.4)$ & $125(35.3)$ & $107(30.2)$ \\
& Female & $42(12.0)$ & $119(34.1)$ & $187(53.7)$ & $91(26.1)$ & $130(37.3)$ & $127(35.9)$ \\
\hline \multirow{2}{*}{ Parents } & None & $46(13.6)$ & $113(34.9)$ & $179(52.9)$ & $106(31.3)$ & $125(36.9)$ & $107(31.6)$ \\
migrated & One parent & $25(20.6)$ & $35(28.9)$ & $61(50.4)$ & $32(26.4)$ & $48(39.6)$ & $41(33.8)$ \\
& Two parents & $36(14.8)$ & $99(40.7)$ & $108(44.4)$ & $75(30.8)$ & $82(33.7)$ & $86(35.4)$ \\
\hline \multirow{2}{*}{ Age } & Early & $19(11.51)$ & $63(38.1)$ & $83(50.3)$ & $54(32.7)$ & $56(33.9)$ & $55(33.3)$ \\
& Middle & $55(15.2)$ & $119(33.0)$ & $186(51.6)$ & $88(24.4)$ & $135(37.5)$ & $137(38.0)$ \\
& Late & $33(18.6)$ & $65(36.7)$ & $79(44.6)$ & $71(40.1)$ & $64(36.1)$ & $42(23.7)$ \\
\hline \multirow{2}{*}{ Geographical } & Urban & $66(18.8)$ & $118(33.7)$ & $166(47.4)$ & $114(32.5)$ & $121(34.5)$ & $115(32.8)$ \\
location & Rural & $36(13.5)$ & $104(39.9)$ & $126(47.2)$ & $84(31.5)$ & $95(35.7)$ & $87(32.7)$ \\
& Urban/Rural & $5(5.81)$ & $25(29.0)$ & $56(61.1)$ & $15(17.4)$ & $39(45.3)$ & $32(37.2)$ \\
\hline${ }^{a} 1=$ hardly agree; $2=$ mildly agree; 3=totally agree. ${ }^{\mathrm{b}} \mathrm{n}(\%) .{ }^{\mathrm{c}}$ School Sexuality Education. ${ }^{\mathrm{d}}$ Sexuality Education Professionalism of Teachers
\end{tabular}

to the same dimension or topic. Next, a frequency analysis was carried out.

Thereafter, inferential statistics were applied to explore differences in adolescents' perceptions (SSE and SEPT) considering their background variables. A multinomial logistic regression was carried out to study possible associations between the predictor variables and the outcome variables in a regression model. In the regression model, main effects of gender, parental migration status, age and geographical location were entered as predictors for the dependent variable SSE and SEPT scores. Levene's test results pointed out assumptions as to homogeneity of variances were consistently met. A $p$ value of .05 was put forward to interpret the results. Statistical analyses were performed using SPSS 19.0.

\section{RESULTS}

The socio-demographic characteristics of the study sample are presented in Table 1. Descriptive analyses showed that the largest proportion of respondents were highly satisfied with the sexuality education they received at school (SSE) (see Table 2).

Student background variables reflected some differences in SSE, especially for the urban rural group (variable geographical location) and in the female group (variable gender) who mainly expressed total agreement. In relation to the variable SEPT, a large proportion of adolescent expressed mild agreement with their teachers' competences regarding sexuality education (SEPT), but with minor differences in comparison to the proportion to less agreement and total agreement. Student background variables seemed to reflect slight differences in SEPT, especially in the late adolescence group (variable age), as they mostly expressed disagreement.

Responses to the open-ended questions are presented in Tables 3 and 4. Results showed that adolescents strongly indicated biological sciences as the main school subject through which sexuality education is provided. Participants also showed that they mostly liked topics related to sexual health; the topic they liked less was pleasure.
Table 3. Reponses to open-ended question: In which school subject have you received sexuality education? $(\mathrm{N}=702)$.

\begin{tabular}{lcc}
\hline \multicolumn{1}{c}{ Area } & $\mathrm{n}$ & $\%$ \\
\hline Exacts & 11 & 1.6 \\
Biological Sciences & 442 & 63 \\
Social Sciences & 100 & 14.2 \\
Arts & 3 & 0.4 \\
Sports & 2 & 0.3 \\
Instrumentals & 9 & 1.3 \\
Others & 52 & 7.4 \\
More than 1 option & 83 & 11.8 \\
\hline
\end{tabular}

Table 4. Responses to open-ended question: What did you like the most about the sexuality education you had? $(\mathrm{N}=702)$.

\begin{tabular}{lcc}
\hline \multicolumn{1}{c}{ Aspects } & $\mathrm{n}$ & $\%$ \\
\hline Topic of Gender & 22 & 3.1 \\
Topic Sexual Health & 447 & 63.7 \\
Topic Sexual Rights & 31 & 4.4 \\
Topic Pleasure & 11 & 1.6 \\
Topic Violence & 15 & 2.1 \\
Topic Diversity & 9 & 1.3 \\
Topic Romantic Relationships & 22 & 3.1 \\
Methodology* & 83 & 11.8 \\
Teacher Attitude** & 39 & 5.6 \\
Others & 23 & 3.3 \\
\hline
\end{tabular}

* Strategies, activities teachers use while teaching sexuality education.

** Confident performance perceived, involvement in the sexuality education classes.

Table 5. Likelihood Ratio Tests linking to background variables $(\mathrm{N}=702)$.

\begin{tabular}{lcc}
\hline Respondent characteristics & SSE & SEPT \\
\hline Gender & $7.79^{*}$ & $7.91^{*}$ \\
Parental migration status & 5.31 & 7.61 \\
Age & 5.09 & $20.79^{* * *}$ \\
Geographical location & $13.38^{*}$ & $13.59^{* *}$ \\
\hline
\end{tabular}

$* \mathrm{p}<.05, * * \mathrm{p}<.01, * * * \mathrm{p}<.001$, based on Chi-square value. 
Table 6. Odds Ratio from multinomial logistic regression for adolescents' perceptions of SSE and SEPT associated with their Sexuality Education satisfaction $(\mathrm{N}=702)$.

\begin{tabular}{|c|c|c|c|c|c|c|c|c|c|}
\hline \multirow{2}{*}{\multicolumn{2}{|c|}{ Respondent characteristics }} & \multicolumn{4}{|c|}{ SSE } & \multicolumn{4}{|c|}{ SEPT } \\
\hline & & \multirow[t]{2}{*}{$\mathrm{b}(\mathrm{SE})^{\mathrm{b}}$} & $\begin{array}{l}\text { Odds } \\
\text { ratio }\end{array}$ & \multirow[t]{2}{*}{ Lower } & \multirow[t]{2}{*}{ Upper } & \multirow[t]{2}{*}{ b(SE) } & \multirow[t]{2}{*}{$\begin{array}{l}\text { Odds } \\
\text { ratio }\end{array}$} & \multirow[t]{2}{*}{ Lower } & \multirow[t]{2}{*}{ Upper } \\
\hline & & & dly agre & & & & & & \\
\hline Gender $^{c}$ & Female & $0.32(0.24)$ & 1.37 & 0.85 & 2.2 & $0.40(0.19)$ & $1.50 *$ & 1.02 & 2.18 \\
\hline \multirow{2}{*}{$\begin{array}{l}\text { Parents } \\
\text { migrated }^{\mathrm{d}}\end{array}$} & None & $-0.17(0.27)$ & 0.83 & 0.49 & 1.42 & $-0.12(0.21)$ & 0.88 & 0.57 & 1.36 \\
\hline & One Parent & $-0.46(0.33)$ & 0.62 & 0.32 & 1.22 & $0.52(0.29)$ & 1.68 & 0.95 & 2.97 \\
\hline \multirow{2}{*}{$\mathrm{Age}^{\mathrm{e}}$} & Early & $0.44(0.34)$ & 1.55 & 0.79 & 3.05 & $0.13(0.26)$ & 1.14 & 0.68 & 1.91 \\
\hline & Middle & $0.07(0.27)$ & 1.07 & 0.62 & 1.83 & $0.61(0.22)$ & $1.85 * *$ & 1.19 & 2.88 \\
\hline \multirow{2}{*}{ G. Location ${ }^{f}$} & Urban & $-0.97(0.53)$ & 0.37 & 0.13 & 1.08 & $-1.15(0.35)$ & $0.31 * *$ & 0.15 & 0.62 \\
\hline & Rural & $-0.55(0.54)$ & 0.57 & 0.19 & 1.65 & $-0.99(0.35)$ & $0.36 * *$ & 0.18 & 0.74 \\
\hline \multicolumn{10}{|c|}{ Total agree (3) vs less agree (1) } \\
\hline Gender & Female & $0.60(0.23)$ & $1.83 * *$ & 1.16 & 2.89 & $0.53(0.19)$ & 1.7 & 1.15 & 2.5 \\
\hline \multirow{2}{*}{$\begin{array}{l}\text { Parents } \\
\text { migrated }\end{array}$} & None & $0.09(0.26)$ & 1.1 & 0.65 & 1.85 & $-0.29(0.22)$ & 0.74 & 0.48 & 1.16 \\
\hline & One Parent & $0.97(0.32)$ & 1.1 & 0.58 & 2.06 & $0.38(0.29)$ & 1.47 & 0.82 & 2.64 \\
\hline \multirow{2}{*}{ Age } & Early & $0.55(0.33)$ & 1.74 & 0.9 & 3.36 & $0.52(0.27)$ & 1.69 & 0.98 & 2.92 \\
\hline & Middle & $0.38(0.26)$ & 1.46 & 0.87 & 2.45 & $1.04(0.24)$ & $2.84 * * *$ & 1.76 & 4.58 \\
\hline \multirow{2}{*}{ G. Location } & Urban & $-1.46(0.51)$ & $0.23 * *$ & 0.08 & 0.62 & $-1.07(0.36)$ & $0.34 * *$ & 0.16 & 0.69 \\
\hline & Rural & $-1.14(0.51)$ & $0.31 *$ & 0.11 & 0.88 & $-0.96(0.36)$ & 0.38 & 0.18 & 0.78 \\
\hline
\end{tabular}

$* \mathrm{p}<.05, * * \mathrm{p}<.01, * * * \mathrm{p}<.001$

${ }^{a}$ Reference category $=$ First value; ${ }^{b}$ Beta value: regression coefficients of the model variables, and Standard error; ${ }^{\mathrm{c}}$ Reference: Male;

${ }^{\mathrm{d}}$ Reference: Two Parents; ${ }^{\mathrm{e}}$ Reference: Late; ${ }^{\mathrm{f}}$ Reference: Urban-Rural.

Information of the model fitting is presented in Table 5. The likelihood ratio results show that gender and geographical location of schools were significantly associated with SSE and SEPT, and age was significantly associated with SEPT, therefore the null hypothesis is rejected with a probability of $5 \%$. The $\chi^{2}$ is $34,264(d f=14)$ for SSE, and 41,904 $(d f=14)$ for SEPT. Regarding the goodness of fit results show that the significance of the model is greater than 0.05 for SSE $(p=0.556)$ and SEPT $(p=0.113)$, which means that the model is suitable for the adjustment of the data.

Concerning adolescents' satisfaction with the sexuality education received (SSE), two background variables were independently and significantly associated (Table 6): gender and geographical location. Female adolescents were 1.83 times more satisfied with the sexuality education they received compared to males; adolescents from urban and rural areas were 0.23 and 0.32 times respectively less satisfied compared to those from urbanrural areas. No associations were found with adolescents' age and migrated parents for SSE.

As to adolescents' perceptions of their teachers' professionalism (SEPT), three background variables were significantly associated: gender, age and geographical location. Female adolescents were 1.50 times more mildly agree with their teachers' competences on sexuality education compared to males. Participants belonging to middle adolescence were more likely to express satisfaction in 2.84 times in comparison with late adolescence group. Adolescents from urban areas were 0.34 times less satisfied compared to those from urbanrural areas. No associations were found with adolescents' parental migration status.

\section{DISCUSSION}

Building on Ecuadorian adolescents' perceptions, this study examined two key aspects in the field of sexuality education in schools: adolescents' satisfaction with sexuality education received in their school (SSE) and their views about the professionalism of their teachers delivering sexuality education (SEPT). The findings of this study reiterate the concern about the perspectives of the target group being disregarded in the design and implementation of sexuality education. In addition, the present research adds to the literature on the possible impact of specific background characteristics onto the studied variables.

Overall, the empirical findings revealed that adolescents are rather highly satisfied with the sexuality education they receive in school, with the highest scores the actual sexuality education they received (SSE), and somehow lower scores regarding the professionalism of their teachers (SEPT).

The rather high scores are in contrast with most literature where students generally express dissatisfaction with the received sexuality education (Alldred, 2007), mainly because of the too strong focus on the biological foundations of sexuality (Walters \& Hayes, 2007) or the irrelevant, boring, repetitive, 'too scientific' and little realistic content (Allen, 2005; Muhanguzi \& Ninsiima, 2011; Adams Tucker et al., 2016) that is often 'too rushed' or 'held too late' (MacDonald et al., 2011). Also the rather relatively high average scores in relation to teachers' professionalism (SEPT) are different from earlier studies that documented how students are not satisfied with the way their teachers handle sexuality education courses, and believe teachers need to improve their knowledge, skills, attitudes and teaching methods (Hilton, 2003; Allen, 2005; Muhanguzi \& Ninsiima, 2011).

To explain these results, we might have to consider the Ecuadorian context. Since learner's engagement is 
influenced by broader cultural dynamics (Adams Tucker et al., 2016) and cultural values often become legitimized through institutional mechanisms resulting in practice codes for teachers and health professionals (Shoveller, 2004). We need to consider the specific socio-dynamics of the study context. Up to date, traditional religious values are still very important in Ecuador, which means it is acceptable to discuss topics related to anatomy, reproduction and STDs/AIDS, yet topics that go beyond this biological perspective are difficult to tackle. Hence, findings may suggest that Ecuadorian adolescents might 'require' less in terms of their sexuality education and are therefore sooner satisfied. This perspective becomes also clear in responses to the open-ended questions. They reiterate the strong focus on biological and health-related topics, that seems to impact the high average satisfaction scores of the participants.

This finding could lead to a biased sexuality education approach and result in a limited conception of human sexuality in adolescents, perpetuating existing problems related with adolescents' sexuality or even generating new inconveniences. The former is also in contradiction with the high teenage pregnancy rate in Ecuador.

Our findings about boys' dissatisfaction with sexuality education and teachers' demeanor are consistent with earlier research (Lupton \& Tulloch, 1996; Hilton, 2003; Muhanguzi \& Ninsiima, 2011), and can be explained by cultural patterns influencing boys' and girls' sexuality behavior whereby they are exposed to different experiences and information about sexuality (Allen, 2005). Measor (2004) states that boys learn more about sexuality from sources excluding adults (media, commercial sources or peers), which may create tensions with the actual sexuality education content and the way teachers handle this in schools. Also, boys are reported to be concerned about being ignorant or having inadequate sexual competences (Forrest et al., 2004; Alldred, 2007), where mass media can answer these concerns in an anonymous way (Lupton \& Tulloch, 1996).

Findings from the older age group's perceptions about their teachers' professionalism (SEPT) suggest a possible mismatch between the sexuality 'career' of adolescents and how they think adults (i.e., their teachers) perceive it. On average, Ecuadorian adolescents of this age group are often already involved in sexual activity (INEC, 2014), which may lead to more mature and complex needs (Allen, 2008). In contrast, older adolescents do not reflect higher scores as to their perceived needs related to sexuality education, which may indicate that they are especially sensitive when it comes to the person addressing sexuality education, rather than to its content.

Our assumption that adolescents with migrating parents would express higher needs regarding sexuality education was not confirmed. A possible explanation is that the physical separation from (a) parent(s) does not necessarily imply a total breakdown of the parental relationship (Olwig, 1999). Further, parental emigration is abundant in the Ecuadorian framework, especially in the region where we set up this research, which might have led to establishing strong social networks that are sufficiently robust to counter the potential vulnerability of these adolescents. Nevertheless, these adolescents still tend to be stigmatized as "children from migrating parents" - as opposed to children from the nuclear family (Pedone, 2006), which could evoke other needs related to sexuality education, but this requires further in-depth analysis.
The variable geographical location had a minimal impact on SSE, with higher needs expressed by adolescents living in urban-rural areas compared to those from urban and rural regions. Findings of other studies are rather inconsistent, with some studies reporting adolescent risky sexual behavior either in urban or rural areas (Folayan $e t$ $a l ., 2015)$, and others specifically indicate early sexual debut and childbearing among rural female adolescents (Doyle et al., 2012). Yet, these findings urge us to reconsider the labels urban and rural (Levine \& Coupey, 2003) as in Ecuador - comparable to many LatinAmerican countries - a 'new rurality' can be observed, showing a pattern of cultural behavior that is increasingly similar to that typically found in urbanized settings (Pascual, 2013). Future research is needed to refine these findings, and to check whether the small differences observed are really relevant and/or interact with other variables, such as the socio-economic status.

Although we observed high levels of satisfaction in adolescents about the sexuality education received (SSE) and the professionalism of their teachers, we stress that our findings have to be interpreted with caution. When we start from a holistic approach towards sexuality education, the adolescents seem satisfied with a biased approach towards their sexuality education. This might result in a narrow vision and a constraint of the realistic comprehension of the concept of sexuality as a natural part of human development (UNESCO, 2015). Building on the criteria put forward in the international literature, this might not equip young people with the knowledge and skills to make conscious, healthy and responsible choices about their sexuality and relationships. Providing sexuality education from a holistic perspective is grounded in human rights - including the rights of the child, and the empowerment of children and young people - (UNESCO, 2009), what also is specified in the Ecuadorian legal framework for children and young people (CNIG, 2019).

\subsection{Limitations}

Some limitations of the present study should be considered. First, the results are limited to the Ecuadorian context and involved respondents from a specific geographical sub-region. Second, the study only involved students from public schools, reaching predominantly adolescents from families with a low or middle socioeconomic status. In private schools (some belonging to religious orders or international schools), sexuality education programs might have been implemented differently, which might evoke other results. Thirdly, adolescents might have experienced difficulties to express their real thoughts regarding sexuality education and concerning their teachers when being questioned in their school setting. Fourth, we have to be aware of the fact that participating adolescents might not have been familiar with the definition of human sexuality as used in the survey and may have started from their (narrow) vision of what sexuality and/or sexuality education implied, or they might have been unaware as to what topics actually can be addressed in sexuality education in schools.

\subsection{Implications}

Our findings have implications for policy makers and researchers. First, the local context has to be taken in account when designing or re-designing sexuality 
education projects. Second, the current study questions whether the Ecuadorian approach of sexuality education in its holistic approach has indeed been implemented. The findings can be used to push reflection about the state-ofthe-art, particularly given the high rates of early pregnancy and gender violence. Third, this study can inspire research and practices to listen to adolescents' voices with regard to sexuality education, in particular to recognize adolescents as sexual beings with sexual rights. Fourth, sexuality education needs to be included in the professional development of teachers, to improve their knowledge and skills, to enable them to answer difficult questions, to address sensitive matters, and to acknowledge students' sexuality education interests. Fifth, the findings indicate differences in participants' sexuality education needs as related to certain background variables, such as gender, age, and geographical location but not for the migration status of parents. Sexuality education programs in schools need to consider these different subgroups' needs and characteristics.

\section{CONCLUSION}

Adolescents participating in the present study expressed rather high satisfaction with sexuality education received at school and less, but still high satisfaction with their teachers' competences regarding sexuality education. Yet, their satisfaction is framed within a biological sexuality education approach. Sexuality education needs to be transformed to encompass other aspects of human sexuality in this target group. Eventually, sexuality education would need to be different for boys and girls. These aspects call for a stronger attention to sexuality education in the Ecuadorian formal education system.

\section{ACKNOWLEDGEMENTS}

The study was supported by the Institutional Cooperation Programme (IUC) between the University of Cuenca (Ecuador) and the Flemish Universities through funding by the Flemish Interuniversity Council (VLIR-UOS).

\section{REFERENCES}

Adams Tucker, L., George, G., Reardon, C., \& Panday, S. (2016). Learning the basics: young people's engagement with sexuality education at secondary schools. Sex Education, 16(4), 337-352. https://doi.org/10.1080/14681811.2015.1091768

Alldred, P., \& David M. E. (2007). Get real about sex: The politics and practice of sex education. London, UK: McGraw-Hill Education.

Allen, L. (2005). Say everything: Exploring young people's suggestions for improving sexuality education. Sex Education: Sexuality, Society and Learning, 5(4), 389-404.

Allen, L. (2008). They think you shouldn't be having sex anyway: Young people's suggestions for improving sexuality education content. Sexualities, 11(5), 573-94.
Bandura, A. (2006). Guide for constructing self-efficacy scales. Self-Efficacy Beliefs of Adolescents, 5, 307337.

Barr, E. M., Goldfarb, E. S., Russell, S., Seabert, D., Wallen, M., \& Wilson, K. L. (2014). Improving sexuality education: The development of teacherpreparation standards. Journal of school health, 84(6), 396-415

Bay-Cheng, L. (2003). The trouble of teen sex: The construction of adolescent sexuality through schoolbased sexuality education. Sex Education: Sexuality, Society and Learning, 3(1), 61-74.

Castro, M., \& Salinas, S. (2017). Diagnóstico de situación del embarazo en la adolescencia en la subregión andina 2016 - 2017. Recuperado de https://www.orasconhu.org/node/3283

CNIG (Consejo Nacional para la Igualdad Intergeneracional) (2019) "Niñez, situación y derechos". Quito-Ecuador. Retrieved from: https://www.igualdad.gob.ec/ninez-y-su-situacion/.

Cohen, J., Byers, S., Sears, H., \& Weaver, A. (2004). Sexual health education: Attitudes, knowledge, and comfort of teachers in New Brunswick Schools. The Canadian Journal of Human Sexuality, 13(1), 1-15

Darré, S., Jerves, E., Castillo, J., \& Enzlin, P. (2015). Sexuality education in Latin America. In: Ponzetti, J. (Ed.). Evidence-Based Approaches to Sexuality Education: A Global Perspective (pp. 277-291). New York, USA: Taylor \& Francis.

Das, A., (2014). Sexuality education in India: Examining the rhetoric, rethinking the future. Sex Education, 14(2), 210-224. https://doi.org/10.1080/ 14681811.2013.866546

DeMaria, L., Galárraga, O., Campero, L., \& Walker, D. (2009). Educación sobre sexualidad y prevención del VIH: Un diagnóstico para América Latina y el Caribe. Revista Panamericana de Salud Pública, 26(6), 485493.

DiCenso, A., Guyatt, G., Willan, A., \& Griffith, L., (2002). Interventions to reduce unintended pregnancies among adolescents: Systematic review of randomised controlled trials. British Medical Journal, 324(7351), 1426-1430.

Doyle, A. M., Mavedzenge, S. N., Plummer, M. L., \& Ross, D. A. (2012). The sexual behaviour of adolescents in sub-Saharan Africa: patterns and trends from national surveys. Tropical Medicine \& International Health, 17(7), 796-807. https://doi.org/10.1111/j.1365-3156.2012.03005.x

Ministerio de Educación del Ecuador. (2012). Constitución de la República, Ley Orgánica de Educación Intercultural y Reglamento General. Quito, Ecuador.

Eisenberg, M., Madsen, N., Oliphant, J., \& Sieving, R. (2013). Barriers to providing the sexuality education that teachers believe students need. Journal of School Health, 83(5), 335-342. https://doi.org/10.1111/ josh.12036

Folayan, M. O., Adebajo, S., Adeyemi, A., \& Ogungbemi, K. M. (2015). Differences in sexual practices, sexual behavior and HIV risk profile between adolescents and young persons in rural and urban Nigeria. PloS one, 10(7), e0129106. 
https://doi.org/101371/journal.pone.0129106

Forrest, S., Strange, V., Oakley, A., \& RIPPLE Study Team. 2004. What do young people want from sex education? The results of a needs assessment from a peer-led sex education program. Culture, Health \& Sexuality, 6(4), 337-354. https://doi.org/10.1080/ 13691050310001645050

Giami, A., Ohlrichs, Y., Quilliam, S., Wellings, K., Pacey, A., \& Wylie, K. (2006). Sex education in schools is insufficient to support adolescents in the 21st century: A summary of sexual and relationship therapy's inaugural debate. $8^{\text {th }}$ Congress of the European Federation of Sexology in Prague, 5 June 2006. Sexual and Relationship Therapy, 21(4), 485490. https://doi.org/10.1080/14681990601019515

Haberland, N., \& Rogow, D. (2015). Sexuality education: Emerging trends in evidence and practice. Journal of Adolescent Health, 56(1-Suplement), S15S21. https://doi.org/10.1016/j.jadohealth.2014.08.013

Helleve, A., Flisher, A., Onya, H., Mũkoma, W., \& Klepp, K. (2011). Can "any" teacher teach sexuality and HIV/AIDS? Perspectives of South African life orientation teachers. Sex Education: Sexuality, Society and Learning, 11(1), 13-26.

Helmich, J. (2009). What is comprehensive sexuality education? Going WAAAAAY beyond abstinence and condoms. American Journal of Sexuality Education, 4(1), 10-15. https://doi.org/10.1080/ 15546120902870315

Hilton, G. (2003). Listening to the boys: English boys' views on the desirable characteristics of teachers of sex education. Sex Education: Sexuality, Society and Learning, 3(1), 33-45. https://doi.org/10.1080/ 1468181032000052144

Hirst, J. (2008). Developing sexual competence? Exploring strategies for the provision of effective sexualities and relationships education. Sex Education: Sexuality, Society and Learning, 8(4), 399-413. https://doi.org/10.1080/14681810802433929

Huberman, A. M., Grounauer, M. M., \& Marti, J. (1993). The lives of teachers. London, UK: Teachers College Press.

Hunt, A., \& Ott, M. A. (2014). Challenges in adapting and implementing evidence-based sex education programs to local contexts. In: Sex Education: Attitude of Adolescents, Cultural Differences and Schools' Challenges. New York, USA: Nova Science Publishers Inc.

Instituto Nacional de Estadísticas Censos (INEC). (2010). Resultados Censo Azuay 2010. Retrieved from http://www.ecuadorencifras.gob.ec/wpcontent/descargas/Manu-lateral/Resultadosprovinciales/azuay.pdf.

Instituto Nacional de Estadísticas y Censos (INEC). (2014). Resultados demografía y salud sexual y reproductiva. Retrieved from http://www.ecuadorencifras.gob.ec/msp-e-inecpresentan-resultados-de-demografia-y-salud-sexual-yreproductiva/.

International Planned Parenthood Federation (IPPF). (2009). From evidence to action: Advocating for comprehensive sexuality education. London, UK: International Planned Parenthood Federation.
Recuperado de: https://www.ippf.org/resource/ evidence-action-advocating-comprehensive-sexualityeducation

Jokhan, M. (2008). Parental absence as a consequence of migration: Reviewing the literature. Social and Economic Studies, 89-117.

Kehily, M. (2002). Sexing the subject: Teachers, pedagogies and sex education. Sex Education: Sexuality, Society and Learning, 2(3), 215-31. https://doi.org/10.1080/1468181022000025785

Kirby, D. (2002). The impact of schools and school programs upon adolescent sexual behavior. Journal of Sex Research, 39(1), 27-33.

Kirby, D., Obasi, A., \& Laris, B. (2006). The effectiveness of sex education and HIV education interventions in schools in developing countries. Technical Report Series-World Health Organization, 938, 103-50

Levine, S., \& Coupey, S. (2003). Adolescent substance use, sexual behavior, and metropolitan status: Is 'urban' a risk factor? Journal of Adolescent Health, 32(5), 350-355. https://doi.org/10.1016/S1054139X(03)00016-8

Linacre, J. (2002). Optimizing rating scale category effectiveness. Journal of Applied Measurement, 3(1), 85-106.

Lupton, D., \& Tulloch, J. (1996). 'All red in the face': students' views on school-based HIV/AIDS and sexuality education. The Sociological Review, 44(2), 252-271. https://doi.org/10.1111/j.1467954X.1996.tb00424.x

MacDonald, J. A., Gagnon, A., Mitchell, C., Di Meglio, G., Rennick, J., \& Cox, J. (2011). Asking to listen towards a youth perspective on sexual health education and needs. Sex Education: Sexuality, Society and Learning, 11(4), 443-457. https://doi.org/10.1080/ 14681811.2011 .595268

Martín, O. (2007). ¿Sexualidad en la escuela? Buenos Aires, Argentina: Editorial SB.

Matthias, R., Lubben, J., Atchison, K., \& Schweitzer, S. (1997). Sexual activity and satisfaction among very old adults: Results from a community-dwelling medicare population survey. The Gerontologist, 37(1), 6-14. http://dx.doi.org/10.1093/geront/37.1.6

Measor, L. (2004). Young people's views of sex education: Gender, information and knowledge. Sex Education: Sexuality, Society and Learning, 4(2), 153166. https://doi.org/10.1080/14681810410001678338

Milton, J., Berne, L., Peppard, J., Patton, W., Hunt, L., \& Wright, S. (2001). Teaching sexuality education in high schools: What qualities do Australian teachers' value? Sex Education: Sexuality, Society and Learning, 1(2), 175-186. https://doi.org/10.1080/ 14681810120052597

Ministry of Education of Ecuador. (2012). Archivo Maestro Instituciones Educativos. Retrieved from: http://educacion.gob.ec/amie

Muhanguzi, F. K., \& Ninsiima, A. (2011). Embracing teen sexuality: Teenagers' assessment of sexuality education in Uganda. Empowering women for gender equity, 25(3), 54-63. http://dx.doi.org/10.1080/ 10130950.2011 .610987 
Olwig, K. (1999). Narratives of the children left behind: Home and identity in globalised caribbean families. Journal of Ethnic and Migration Studies, 25(2), 267284. https://doi.org/10.1080/1369183X.1999.9976685

Oulton, C., Day, V., Dillon, J., \& Grace, M. (2004). Controversial issues - teachers' attitudes and practices in the context of citizenship education. Oxford Review of Education, 30(4), 489-507. https://doi.org/10.1080/0305498042000303973

García-Pascual, F. (2013). ¿Un nuevo modelo rural en Ecuador? Cambios y permanencias en los espacios rurales en la era de la globalización. Íconos-Revista de Ciencias Sociales, (29), 77-93. https://doi.org/10.17141/iconos.29.2007.242

Pedone, C. (2006). Los cambios familiares y educativos en los actuales contextos migratorios ecuatorianos: Una perspectiva transatlántica. Athenea Digital. Revista de Pensamiento e Investigación Social, (10), 154-171.

Preston, M. (2013). 'Very very risky': Sexuality education teachers' definition of sexuality and teaching and learning responsibilities. American Journal of Sexuality Education, 8(1-2), 18-35. https://doi.org/10.1080/15546128.2013.790223

Rijsdijk, L. E., Bos, A. E., Ruiter, R. A., Leerlooijer, J. N., de Haas, B., \& Schaalma, H. P. (2011). The world starts with me: A multilevel evaluation of a comprehensive sex education program targeting adolescents in Uganda. BMC Public Health, 11(1), 112. https://doi.org/10.1186/1471-2458-11-334

Santelli, J., Ott, M. A., Lyon, M., Rogers, J., Summers, D., \& Schleifer, R. (2006). Abstinence and abstinenceonly education: A review of US policies and programs. Journal of Adolescent Health, 38(1), 72-81. https://doi.org/10.1016/j.jadohealth.2005.10.006

Schmidt, S., Wandersman, A., \& Hills, K. (2015). Evidence-based sexuality education programs in schools: Do they align with the national sexuality education standards? American Journal of Sexuality Education, 10(2), 177-195. https://doi.org/10.1080/15546128.2015.1025937

Shoveller, J., Johnson, J., Langille, D., \& Mitchell, T. (2004). Socio-cultural influences on young people's sexual development. Social Science \& Medicine, 59(3), 473-87. http://dx.doi.org/10.1016/j.socscimed.2003.11.017

Simovska, V., \& Kane, R. (2015). Sexuality education in different contexts: limitations and possibilities. Health Education, 115(1), 2-6. https://doi.org/10.1108/HE-102014-0093

Suellentrop, K. (2011). What works 2011-2012: Curriculum-based programs that help prevent teen pregnancy. Washington D.C., USA: National Campaign to Prevent Teen and Unplanned Pregnancy. Available at http/Thenationalcampaign.Org/ Resource/What-Works.

Tenorio-Ambrossi, R. (2004). La intimidad desnuda. Sexualidad y cultura indígena. Quito, Ecuador: Ed. Abya-Yala.

Thomas, F., \& Aggleton, P. (2016). School-based sex and relationships education: Current knowledge and emerging themes. In: Sundaram V., Sauntson H. (Eds). Global perspectives and key debates in sex and relationships education: Addressing issues of gender, sexuality, plurality and power, 13-29. London, UK: Palgrave Pivot.

UNESCO. (2015). Emerging evidence, lessons and practice in comprehensive sexuality education. A global review. http://unesdoc.unesco.org/images/ 0024/002431/243106e.pdf.

UNESCO. (2009). International technical guidance on sexuality education. An evidence-informed approach for schools, teachers and health educators. http://unesdoc.unesco.org/images/0018/001832/18328 1e.pdf.

Walters, A., \& Hayes, D. (2007). Teaching about sexuality: Balancing contradictory social messages with professional standards. American Journal of Sexuality Education, 2(2), 27-49.

Wilson, K., Goodson, P., Pruitt, B., Buhi, E., \& DavisGunnels, E. (2005). A review of 21 curricula for abstinence-only-until-marriage programs. Journal of School Health, 75(3), 90-98. https://doi.org/10.1111/j.1746-1561.2005.00003.x

World Health Organization (WHO). (2010). Standards for sexuality education in Europe: A framework for policy makers, educational and health authorities and specialists. Cologne, Germany: Federal Centre for Health Education

\section{ANEXO}

\section{Questionnaire to assess students' perceptions regarding sexual education}

Dear Student, this questionnaire aims to know your perceptions about sexual education. Please read the questions given below and answer them in the most accurate way. Your answers will be strictly confidential. Please answer all questions.

PART I. The following questions are focused in knowing some general demographics characteristics. Please read the items and mark a cross in the category that belongs to you:

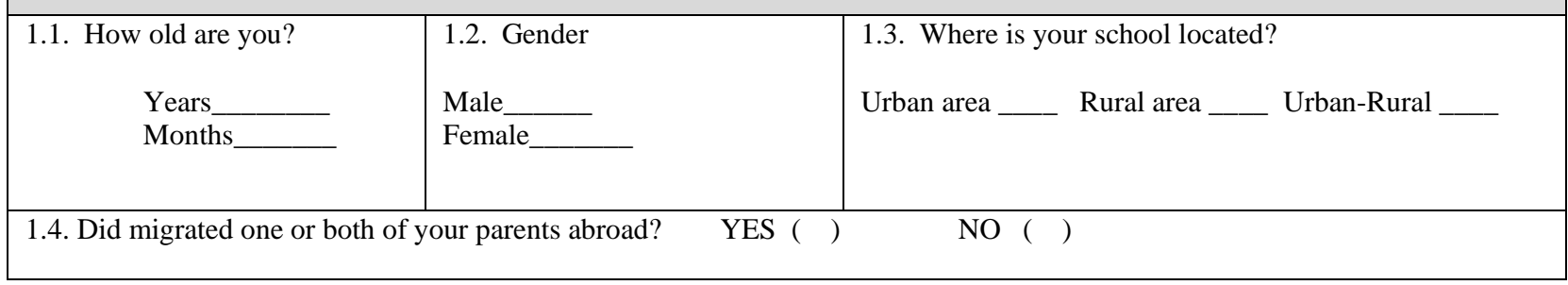


PART II. This part aims to know the perceptions about your experiences regarding Sexual Education.

2.1. Have you received Sexual Education in your current school?

\begin{tabular}{|c|c|c|c|}
\hline Yes & $\begin{array}{l}\text { If your answer was Yes, just answer the part A } \\
\text { of the follow question (questions } 2.2 \text { to } 2.8 \text { ) }\end{array}$ & No & $\begin{array}{l}\text { If your answer was Not, just answer the part B } \\
\text { of the follows question (questions } 2.9 \text { and } 2.10 \text { ) }\end{array}$ \\
\hline
\end{tabular}

PART A (if your answer was yes)

2.2. In which courses have you had sexual education classes?

2.3. What did you like the most about sexual education classes that you had?

Please read all the statements presented bellow and indicate the grade of agreement of disagreement with each one, marking one of the follows alternatives:

1. Total agree

2. Quite agree

3. Mildly agree

4. Slightly Disagree

5. Somewhat disagree

6. Strongly Disagree

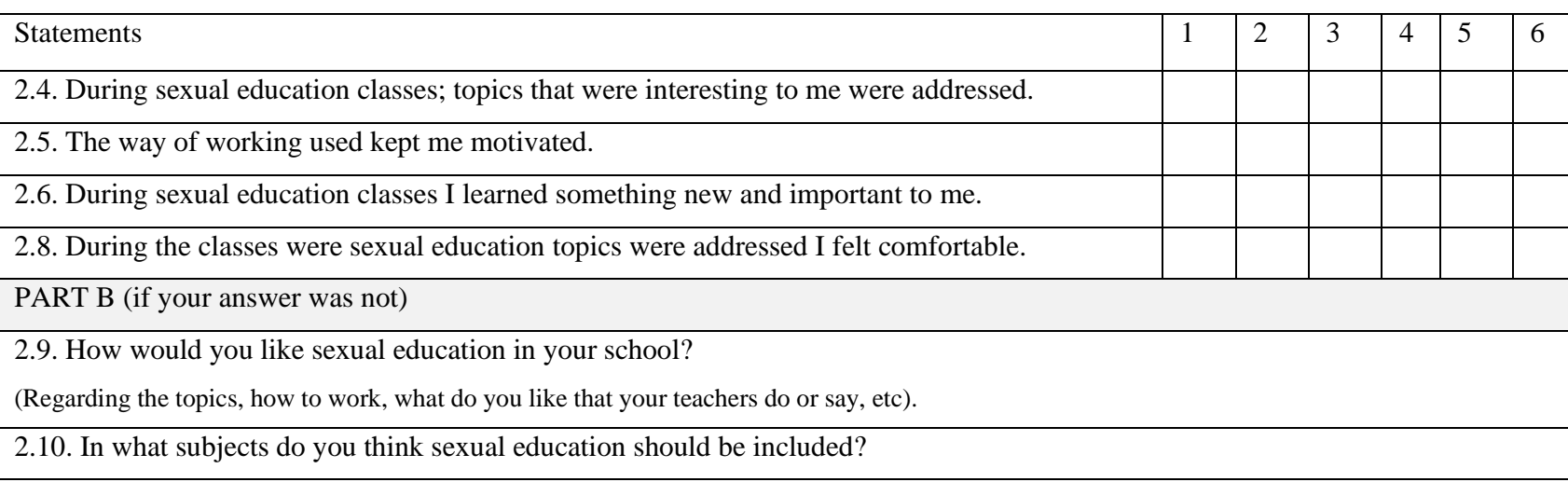

\section{PART III. This part aims to know your perceptions respect of the role of your teachers in relation with sexual education}

Please read the statements presented bellow and indicate the grade of agreement of disagreement with each one, marking one of the follows alternatives:

1. Total agree

2. Quite agree

3. Mildly agree

4. Slightly Disagree

5. Somewhat disagree

6. Strongly Disagree

\begin{tabular}{|c|c|c|c|c|c|c|}
\hline Statement & 1 & 2 & 3 & 4 & 5 & 6 \\
\hline $\begin{array}{l}\text { 3.1. My teachers could clearly express their views regarding aspects related to sexual educatic } \\
\text { in front of us. }\end{array}$ & & & & & & \\
\hline $\begin{array}{l}\text { 3.2. My teachers could get their students to develop positive attitudes toward sexuality *. } \\
* \text { (Positive attitudes are opinions and values about the actions that lead to responsibly handle sexuality) }\end{array}$ & & & & & & \\
\hline $\begin{array}{l}\text { 3.3. My teachers could get motivate us to feel comfortable as we address issues relating to sex } \\
\text { education. }\end{array}$ & & & & & & \\
\hline $\begin{array}{l}\text { 3.4. My teachers could get their students to develop skills * so we can responsibly handle our } \\
\text { sexuality. } \\
* \text { (The skills are behaviors that students can practice) }\end{array}$ & & & & & & \\
\hline $\begin{array}{l}\text { 3.5. My teachers would consider time to work sex education although they have to address } \\
\text { other topics in their classes }\end{array}$ & & & & & & \\
\hline $\begin{array}{l}\text { 3.6. My teachers could get their students to improve their knowledge about sexuality } \\
* \text { (Knowledge is to have information about facts related to sexual education in a comprehensive way and } \\
\text { adjusted to different ages). }\end{array}$ & & & & & & \\
\hline
\end{tabular}

